\title{
Adaptive reuse of industrial buildings in a new precinct in Auckland's CBD
}

\author{
Dr Lydia Kiroff \\ Xiaotian Tan \\ Faculty of Technology and Built Environment \\ UNITEC Institute of Technology \\ Auckland, New Zealand \\ lkiroff@unitec.ac.nz
}

\begin{abstract}
The conversion of former industrial buildings and identifying heritage as a commodity has become a pervasive trend, especially over the last decade. Adaptive re-use of old industrial buildings is often seen as an alternative to demolition and replacement and as the primary development solution for an existing building when it no longer meets expectations. Building adaptation plays an important role in urban regeneration through the preservation of urban heritage while achieving major economic benefits. The aim of this paper is to examine the key areas of consideration involved in the conversion of former industrial buildings in a new large-scale precinct in Auckland's CBD (central business district). A case study research, which employs multiple sources of empirical evidence, such as fieldwork, documentary research and semi-structured interviews, was considered most appropriate as it offered a multi-faceted approach to the research investigation. The findings of the study indicate that preserving historical character through adequate design approaches was the main area of consideration for all parties - the architect, structural engineer, urban planner, heritage advisor and property developers. However, creating economic value and commercial potential through careful financial considerations was also particularly important for the property developers. Furthermore, this study identified that property developers, responsible for the initial physical upgrading of old buildings, played a leading role in urban redevelopment and were the main initiators of urban transformation. Until recently, adaptive re-use has received limited attention in New Zealand as new builds have been perceived as the sole answer to client demands. However, building adaptation is proving to be an effective alternative in urban regeneration campaigns through the creation of attractive work environments. This research provides the foundations for an overall integrated approach to adaptive re-use which is at the heart of post-industrial real estate development driven by proactive property developers.
\end{abstract}

Keywords-adaptive re-use; industrial buildings, urban regeneration, Auckland's CBD

\section{INTRODUCTION}

Adaptive reuse of buildings is often seen as a viable alternative to demolition. Various studies in the literature examine building adaptation as a juxtaposition of benefits (economic, environmental and social) and barriers (mainly structural and planning). Furthermore, a number of theoretical models, estimation tools and assessment methodologies have been developed with the purpose to determine a building's potential for adaptive reuse and help stakeholders in the decision-making process. Adaptive re-use is considered as an alternative way to improve a building's performance while simultaneously reducing its environmental loading. However, limited published research explores the intangible value added through building adaptation, its significance as an important resource in place-making strategies and its role in place branding. This study offers a multi-faceted approach which has been applied to a large-scale precinct development in Auckland's CBD (central business district) and provides an indepth discussion of the implications of the stakeholders' multiple perspectives. Over the last years adaptive re-use has become a more attractive investment proposition for property developers and a prominent strategy in the redevelopment of Auckland's central and inner city. This paper provides policy makers and key decision makers with the underlying factors that need to be considered when implementing an adaptive reuse policy as part of their sustainability strategy.

\section{CONTEXT}

\section{A. An overview of adaptive reuse}

The conversion of former industrial buildings and identifying heritage as a commodity in the creative economy has become a pervasive trend, especially over the last decade [2] [6] [14] [51] [52]. Various definitions of adaptive reuse with a certain degree of similarity abound in the literature. Adaptive reuse is described as a process which changes or modifies a disused building and repurposes it while retaining its cultural heritage value [1] [4] [31]. The adaptive reuse of an existing building stock has been recognised as having a significant impact upon the built environment. The redevelopment and upgrade of derelict industrial buildings in city fringe areas and their complete transformation into fashionable districts has been recognised as an important part of regeneration programmes [7]. Thus, the relics of the industrial past become integrated as core elements of postindustrial urban landscapes of production and consumption [45].

Building conversion nowadays has been influenced by the ever-increasing demand for residential and commercial space 
[14]. Building adaptation has been considered as a process to improve the performance of buildings financially, socially and environmentally [5] [7] [36] [43] and plays an important role in the built environment [35]. The type and form of conversions depend to a great extent on the original and intended use of the building. Although building conversions have financial and legal constraints, they also present attractive opportunities for creative interpretations [14] [36] [52]. The success of a building conversion is determined by the preservation of the building's heritage significance skilfully overlaid with contemporary uses thus adding value for the future [1]. Reference [31] has clear guidelines regarding building adaptations which need to retain the cultural heritage value; avoid dominating the original form and fabric; and blend any new work with the old. Re-using well-constructed former factories and warehouses through adapting them for contemporary uses "makes them a scarce commodity" with major economic benefits [54]. Inner city locations and old industrial buildings, which embody symbolic meaning, tend to attract creative and other professionals with their aesthetic qualities and unique ambience [29] [37] [38] [54]. The built form provides an appropriate environment for the area's business and creative activities to develop and prosper [40]. In comparison, standard office buildings lack such symbolic values and the embodiment of historical narratives.

\section{B. Economic benefits of adaptive reuse}

Certain financial gains and returns are commonly associated with the adaptive reuse of historic buildings. Embodied energy savings resulting from retaining the building become especially relevant in the light of rising energy costs in the future [1]. In some instances adapting existing building stock proves a cheaper alternative to a demolition and reconstruction. Demolition, in general, is an expensive, wasteful, messy, disruptive and dangerous process that can cause a lot of nuisance and expends more energy and waste than adaption [14]. Often due to the big volume and complicated structure of some factory buildings, demolition costs are higher than those for reconstruction [51]. Furthermore, building conversions aim for economic use of materials, space, energy and a better utilization of the infrastructure [44] and have the added benefit of a shorter construction time [2] [14] [49] [36]. Adaptive reuse could also be considered as a greater employment generator in comparison to new construction. Refurbishments, which typically involve labour-intensive activities, require 25\% more employment per square meter of floor area than new builds [36].

However, studies in the literature elaborate on the difficulties for building adaptation to reach cost efficiency. This cost efficiency seems to equal to zero if economic return is the only pursuit in the conversion process. In such instances, adaptive reuse could be considered as a very expensive investment, especially when the intangible non-economic values remain overlooked [53]. This is especially true in the cases of complex adaptations or poor build quality which can drive up adaptive reuse costs higher than new build even though construction periods may be shorter because fewer or

Identify applicable sponsor/s here. If no sponsors, delete this text box. (sponsors) no demolition is carried out [52]. A contributing argument to this discourse is that since new build is relatively more straightforward, it might be more profitable to make a new building [46] [5]. The materials and components used in historic buildings may influence the economic viability of working on an adaptation project [7]. In addition, capital costs and future running costs should also be taken into account [53]. The ongoing maintenance costs of an adaptive reuse project would usually be higher than a new-build project as buildings age over time [14] [6]. In general, various adaptation schemes are worthwhile in most cases from an economic point of view; only some dilapidated buildings are best demolished considering their high adaptation costs and future maintenance costs.

\section{Environmental benefits of adaptive reuse}

Adaptive reuse of buildings has a major role to play in the sustainable development of communities offering significant environmental benefits, such as the retention of the original building's "embodied energy". This is the energy consumed by all of the processes associated with the production of a building, from the acquisition of natural resources to product delivery. By reusing buildings, their embodied energy is retained, making the project much more environmentally sustainable than entirely new construction [1]. Adaptive reuse is inherently sustainable as energy consumption and the generation of waste can be reduced, pollution and waste can be minimized during reconstruction, and pressure of communication can be released [5] [14] [51] [52]. The reuse of building materials usually involves a saving of approximately 95 per cent of embodied energy that would otherwise be wasted [1]. The materials generally retained in an existing converted building are normally much more energy intensive [25]. In comparison, demolition could not be considered as being an environmentally-friendly process due to a significant material waste [14] [52].

Adaptive reuse also offers a safer and sustainable building site with existing infrastructure and materials as it lessens the amount of disturbance caused by dangerous materials, pollution to the ground and the hazard of falling materials and dust. It provides the convenience of working on a site with reduced downtime from inclement weather [7]. Furthermore, adaptive reuse provides the opportunity for older buildings, constructed with quality materials and having better energy consumption, to gain a longer useful life [36]. The existing building stock could also possibly reduce dramatically the environmental load on the built environment in the coming 20 or 30 years [5]. However, despite the various environmental advantages, an improved internal or external environment may not always be the result of a refurbished building, and also the building's new use may not always be compatible with the current surroundings [14].

\section{Social benefits of adaptive reuse}

The retention and adaptation of existing buildings offers long term social benefits - architectural, cultural and historic, aiming to suit the ever-changing community. The thoughtless demolition of historic buildings is now perceived not only as an ecological waste but also as eradication of local identity, 
cultural heritage and socio-economic values [11]. Building adaptation offers a means of retaining the style and character of buildings [2]. When executed well, the potential for longer benefits are two-fold: for the communities that value them and for restoring and maintaining the heritage significance of the building itself [1] [7] [49]. Communities continue to recognise that future generations can profit from the conservation of heritage buildings through addressing the ever-increasing demand for properties and land [1] [14].

Buildings could be considered as a physical embodiment of cultural memory and historical narratives in terms of their conditions and materiality [18]. Industrial heritage is also a testament to the course of civilisation and can be important in providing traces of our past [51]. Furthermore, it can contribute to the development of new stories and identities through the process of urban regeneration [25]. However, despite people's perceptions of industrial buildings having heritage, social and cultural value, the common practice of excluding them from the list of heritage buildings with cultural and social significance has led to their ubiquitous demolition [52].

In contrast, there is a social argument against building adaptation, despite the positive social benefits such as intrinsic heritage values, whereby the standards required by contemporary buildings are hard to achieve by old existing buildings [7]. One example are the indoor air quality and acoustic and thermal performance requirements which are of significant concern [52]. Issues of legislative compliance, fire safety, accessibility for the disabled and others, limiting the scope and extent of the adaptation, should also be addressed properly [36]. The development of specific policies and strategies to encourage the adaptive reuse of buildings [6] and the compliance with different performance standards [52] offer a possible solution to this dilemma. Overall, the social advantages of building conversion far outweigh the disadvantages. As there are architectural, cultural, and historical benefits of building conservation, adaptive reuse of buildings is playing an increasingly important role particularly in the context of urban regeneration.

\section{E. Heritage as a commodity in urban regeneration}

Urban heritage and adapted industrial buildings play a key role in place branding and are recognised as important resources in place making strategies [15]. The physical properties of the built form give identity to a city on a macro scale and contribute to a great extent to a sense of place on a micro scale alongside wide-ranging economic activity. Built heritage, in particular, plays an important role for the postindustrial city and has great potential as a "place-identity generator" [20]. Heritage, which plays a key role by evoking images of a nostalgic past through the use of cultural and historical references, is seen as lending “a desired aura” to a place [32, p.3615]. Thus, successful place branding depends heavily on the distinctive characteristics of a place and is used as a powerful marketing tool associated with the creation of unique identities [16] [22] [33] [34].

The process of "recycling of old buildings and districts" in proximity to the CBD leads ultimately to "the construction of a new urban imagery through the production of new urban spaces" [47, p.209] and the emergence of "post-industrial urban landscapes" [17, p.1004]. In addition, the recycling process is seen as a way of preserving and restoring the distinctive built environment [28]. Consequently, the emerging post-modern urban landscapes become a distinctive feature of the inner city [27]. The process involves the formation of distinctive new industrial spaces in the postmodern inner city [48] and creates a new image and identity for them [47]. Image is considered as an important element in urban regeneration marking a transition from "a polluted and blue-collar" industrial past to a "vibrant, stylish, confident, cosmopolitan and innovative” creative future [22, p.354].

\section{F. Factors influencing decision-making in adaptive reuse}

A few different evaluation tools for adaptive reuse have been developed to determine the potential for building adaptation and help industry professionals in the decisionmaking process. The majority of evaluation models in the literature are based on the economic - environmental - social philosophy.

Reference [50] use a range of interdependent selection criteria for their methodology - cultural, economic, architectural, environmental, social and continuing management. The cultural criterion focuses on the building's historical and artistic value and the conditions of integrity and authenticity. The economic aspect explores the potential market, future profits and financial implications, the opportunity for subsidies and the size of the initial and ongoing maintenance investment. The architectural criterion examines the physical condition of the building, its architectural character and in-built flexibility, structural suitability and compliance with current building code requirements. The environmental facet considers site specificities and contextual value, potential environmental effects, land use and regional development policies. The social viewpoint appraises the integration of new and existing uses and evaluates the level of public interest, public awareness and community involvement. The continuity aspect investigates adequate protection and management systems, future change feasibility and ecological and cultural sustainability.

Alternative models in the literature, such as the Adaptive Reuse Potential (ARP) model, provide a means by which the industry can identify and rank existing buildings that have high potential for adaptive reuse [36]. The ARP model is an evaluation tool for estimating the useful life of buildings based on obsolescence criteria - physical, economic, functional, technological, social and legal. Physical obsolescence can be measured by an examination of maintenance policy and performance. Proper maintenance prolongs the useful life of a building. Economic obsolescence can be measured by the building's location in relation to a city centre. A building's useful life is effectively reduced if the building is located in a relatively low populated area. Functional obsolescence can be measured by determining the extent of flexibility embedded in a building's design. The inflexibility of building layouts effectively reduces useful life. Technological obsolescence can be measured by the building's use of operational energy. 
High levels of energy required to provide occupant comfort have a negative impact on useful life. Social obsolescence can be measured by the relationship between building function and the marketplace i.e. any dependence on external income reduces useful life. Legal obsolescence can be measured by the quality of the original design. Good quality design and construction prolong a building's useful life.

Reference [7] provide a comprehensive review of the factors influencing the decision to adopt an adaptive re-use strategy. First, cost effectiveness and rising energy costs, associated with new construction, impact on the reuse of existing buildings stock. Second, lifecycle issues are with regard to extending the lifecycle of a building, increase the ability to accommodate new technologies and facilitate the adaptation to suit changing working practices. Third, the changing perceptions of buildings in terms of ability to provide multiple uses and a growing appreciation for built heritage have led to an increase in the available building stock by adapting existing and heritage buildings for new uses. Fourth, various governmental incentive schemes aim to encourage sustainable development, particularly in the case of heritage buildings, through the use of financial incentives.

\section{RESEARCH APPROACH}

A case study research was considered most appropriate as it offered a multi-faceted approach to the research investigation. The case study is a preferred strategy when the focus is on a contemporary phenomenon within a real life context [8]. The City Works Depot (CWD) is one of Auckland's latest largescale precinct developments located at the corner of Wellesley, Nelson and Cook Streets on the western Auckland CBD fringe. This adaptive reuse project with a total value of approximately $\$ 44$ million has won several national architectural awards. The 3.5 ha property with a rich history of over 50 years has undergone a complete transformation from an industrial complex housing garages, workshops and parking to a fashionable mixed-use precinct with upmarket retail, fine dining and a creative hub.

\section{A. Data collection methods}

Multiple sources of empirical evidence, such as semistructured interviews, fieldwork in the CWD and documentary research, were the chosen data collection methods within the case study. The purpose of combining these different methods was to gain in-depth understanding of the conversion of this large former industrial complex in the specific Auckland context and examine the study's research problem from different perspectives. Conducting participant observations in conjunction with interviewing and document analysis allows for the triangulation and substantiation of the findings [39]. The use of such multiple sources of evidence and a variety of types of data are a major strength of the case study approach [8] [9] [13]. The collected qualitative data painted a richer picture of the area's historical background, socio-economic profile and character building stock which would not have been possible if interviews had been used as a sole method. A clear advantage that the case study approach offered was a "greater opportunity to delve into things in more detail and discover things that might not have become apparent through more superficial research” [13, p.53].

\section{B. Fieldwork in the City Works Depot}

The qualitative gathering of "soft data" [42, p.139] began with fieldwork in the CWD. A number of field trips were made in 2014 with the aim to identify the preferences of the precinct firms in terms of buildings as business locations and take photographs of the buildings' exterior. Photographic evidence, based on "created" still images is defined in social research as "fieldwork photography", which is the foundation of "visual sociology - a process of seeing guided by theory" [23, p.717]. The fieldwork resulted in a collage of images of the precinct's spacious, architecturally designed and refurbished sheds and helped in capturing rich contextual information and in-depth understanding of the local setting.

\section{Documentary research}

Both text-based and image-based documentary research was considered alongside the fieldwork and interviews to provide data on the precinct's area and describe a richer contextual setting. Documentary research has definite advantages: provides a relatively easy access to the sources and is an inexpensive and cost-effective method of getting data [13]. Still images - photographs, were used as a source of image-based documentary data. The CWD's historical background was produced as a result of a mixture of textbased and image-based documentary sources: academic literature, professional magazine articles and web sources; and visual images - historical aerial photographs of the precinct over a period of 50 years, sourced from the Auckland Council's GIS Viewer. The characteristics of these "found" images (film, photographs, paintings, graffiti or artefacts) are that they already exist and have been produced by other people as a visual record of an event or a group [13, p.230]. Furthermore, the documentary research focused on the architectural drawings, zoning requirements from the Auckland Council District Plan, property rates from the Auckland Council GIS Viewer, and a search of the New Zealand Historic Places Trust's (NZHPT) register. A specifically designed document analysis framework was used to help the research investigation.

\section{Semi-structured interviews}

Semi-structured, face-to-face, in-depth interviews were the major method of empirical data collection and followed the documentary research and fieldwork in the CWD. In-depth interviews are especially suitable to obtain a more detailed understanding of certain concepts within a particular context [19]. Semi-structured interviews are appropriate when sufficient information about the study topic is gathered in advance to guide the discussion [41]. The main objective of the interviews was to explore the key areas of consideration involved in this adaptive reuse development. Semi-structured interviews were appropriate for this study as they allowed the use of a mix of pre-planned questions and unstructured conversations resulting in detailed, complex answers [41]. They also permit a level of flexibility as the interviewees have the opportunity to develop own ideas and speak more widely 
on the issues and their perception of reality thus contributing additional contextual information [8] [13]. The additional information revealed through the unstructured discussion of the interviews provided new dimensions to the research problem which were not obvious at the fieldwork and document analysis phases. Four different sets of questions guided the semi-structured interviews with the property developers, project architect, structural engineer, urban planner from Auckland Council and a heritage advisor from the Design Panel of Auckland Council. Data obtained from the interviews with the property developers was useful for investigating their investment motives, the financial considerations in such building conversions and the property's tenant mix selection criteria. Data gathered from the remaining interviews was essential to uncover the design considerations architectural, structural and planning, associated with such conversions.

\section{FINDINGS AND DISCUSSION}

\section{A. Building profile and historical background}

The converted 100-meter long former industrial complex located on the western side of the CBD and on a major motorway interchange, has an innovative mix of uses and activities which include retail, showroom, dining, commercial offices, venues and hospitality spaces, with 900 car parking spaces. The industrial-style, three-level, fanlight-topped building was originally built along the hillside in the 1960s and was the first prefab construction in the country.

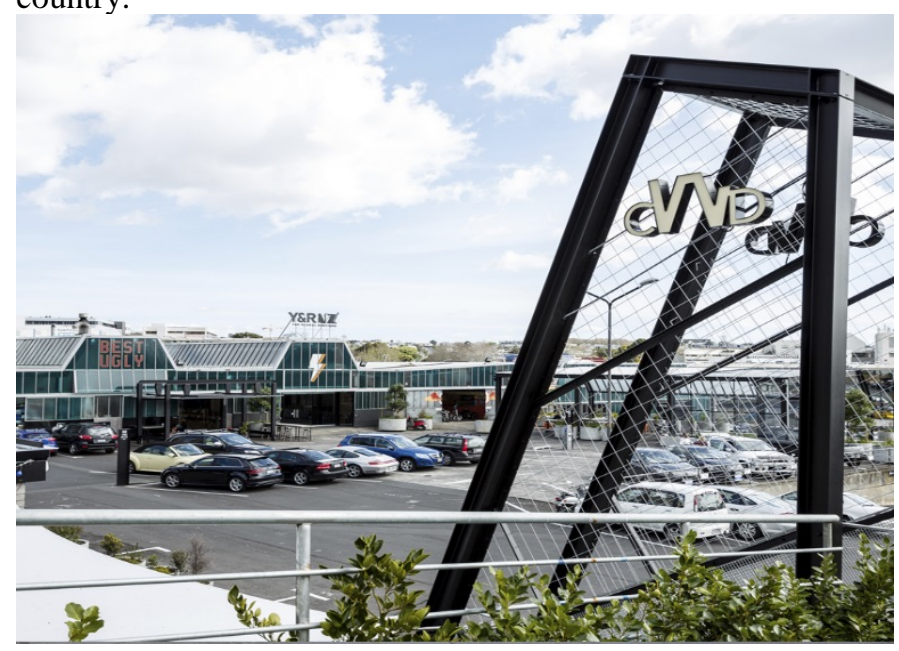

Figure 1. The City Works Depot Project - Wellesley St Frontage (2014)

The old City Workshops were originally designed by former Auckland City architect Ewen Wainscott in the late 1960s and opened in 1968. The building was awarded a bronze medal for industrial architecture at the New Zealand Institute of Architects (NZIA) awards in 1968 and silver in 1969 [3]. The NZIA Award Jury fully appreciated the qualities of the original building structure and described it as "a credit to the city and a good piece of urban design” [3, p.34]. Additionally, it was considered as a rejuvenating change from the typical Council Workshop's corrugated iron sheds [12]. The multipurpose complex provided admin offices, facilities for street and drainage repair, the council vehicle garaging, electrical maintenance, water supplies laboratory investigation, but also served as a petrol oil and weighbridge depot for council buses, trucks, and vehicles [12]. These departments were crucial for the future development of the city centre. The three-level complex has been unique from the very beginning; Auckland's CBD was built out of these sheds, as the Council was a governing body as well as a construction company at that time.

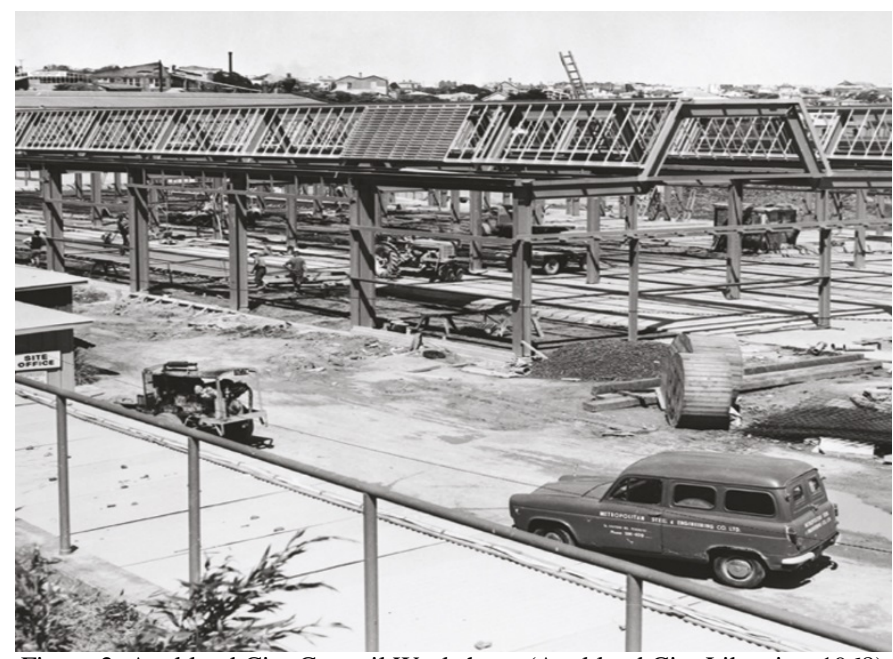

Figure 2. Auckland City Council Workshops (Auckland City Libraries, 1968)

The Auckland City Council used the precinct up until 1991. In 1995, the property was sold to a Chinese businesswoman, Nina Hsu, but after that resold a few times to different investors. Each property transaction was accompanied by demolition threats until a property developer, Doug Rikard-Bell, acquired the site in 2008. He proposed a grand, \$60 million, 20-building, commercial-residential development plan, Rhubarb Lane, which included shopping centres, restaurants, a hotel, over 1,000 residential units and commercial spaces. However, the proposed multiple architectdesigned Rhubarb Lane precinct was unsuccessful as it failed to get enough sales and was finally abandoned. The current private property developers/owners, with extensive experience in property development, bought the complex in 2012. They planned to retain the buildings and upgrade them to preserve the depot's history and enhance its old features. However, the building is not officially recognised as a heritage building and is not on the NZHPT register. Nowadays, the CWD is home to the new Best Ugly Bagels restaurant, Food \& Truck Garage, and Dry \& Tea, as well as existing draw cards Brothers Brewery \& Shed Five Cafe. It is also home to the advertising agency $\mathrm{Y} \& \mathrm{R}$, film and digital agency Augusto, and international magazine company Bauer.

The CWD had three stages of development with Sheds 1 \& 2, which house The Food Truck Garage and Dry \& Tea being in the first two stages. The final stage 3, designed to have a similar look and feel to Sheds $1 \& 2$, but on a much larger scale, features a spectacular, spiral staircase. 


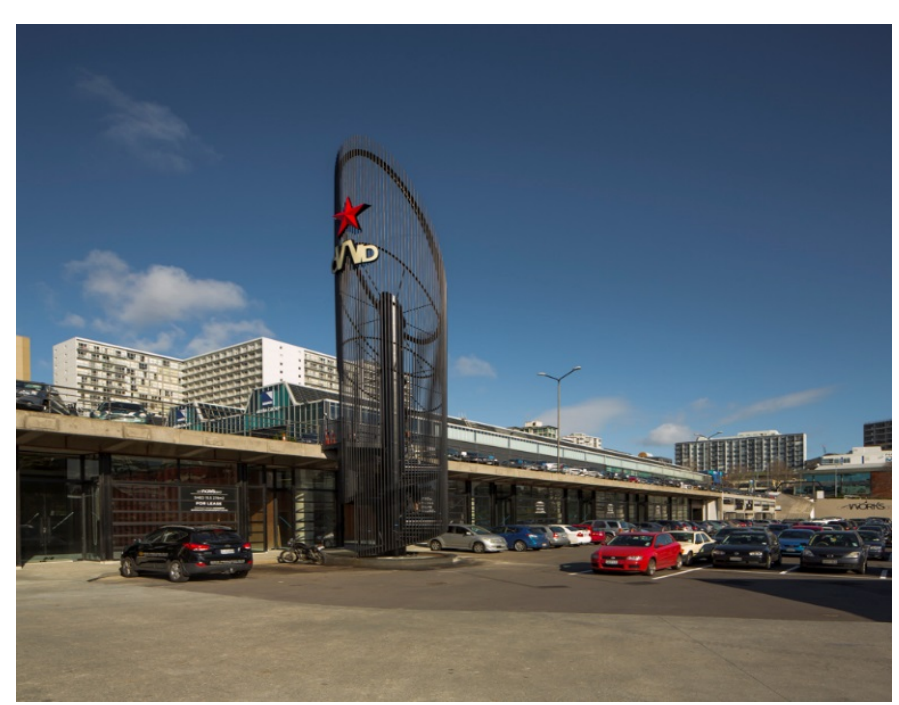

Figure 3. CWD final stage - Shed 15 (2014)

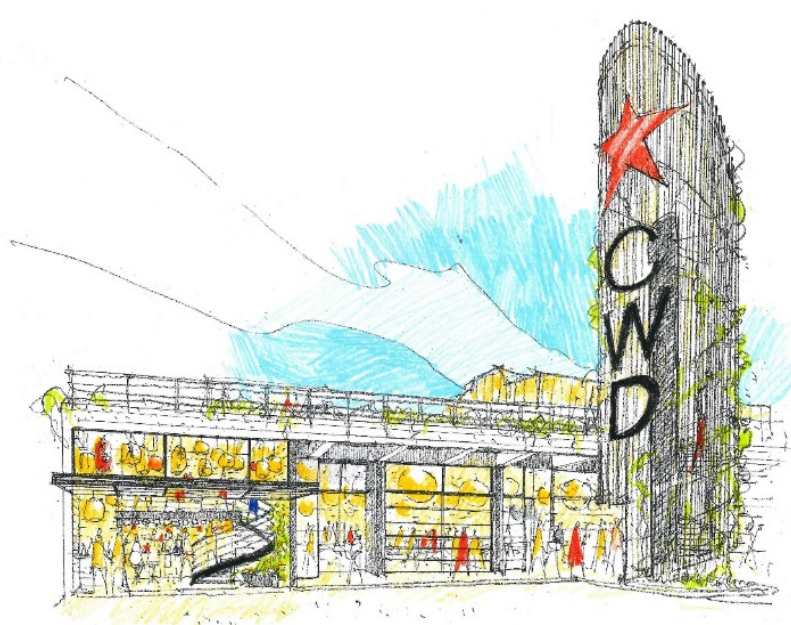

Figure 4. CWD Shed 15 exterior sketch (image supplied by the architect)

The historical aerial photographs of the project site from 1940 to 2010 show that this area has been traditionally dominated by industrial activity. The industrial flavour has continued until recent times, predominantly due to the zoning requirements of the area and its fewer development opportunities.
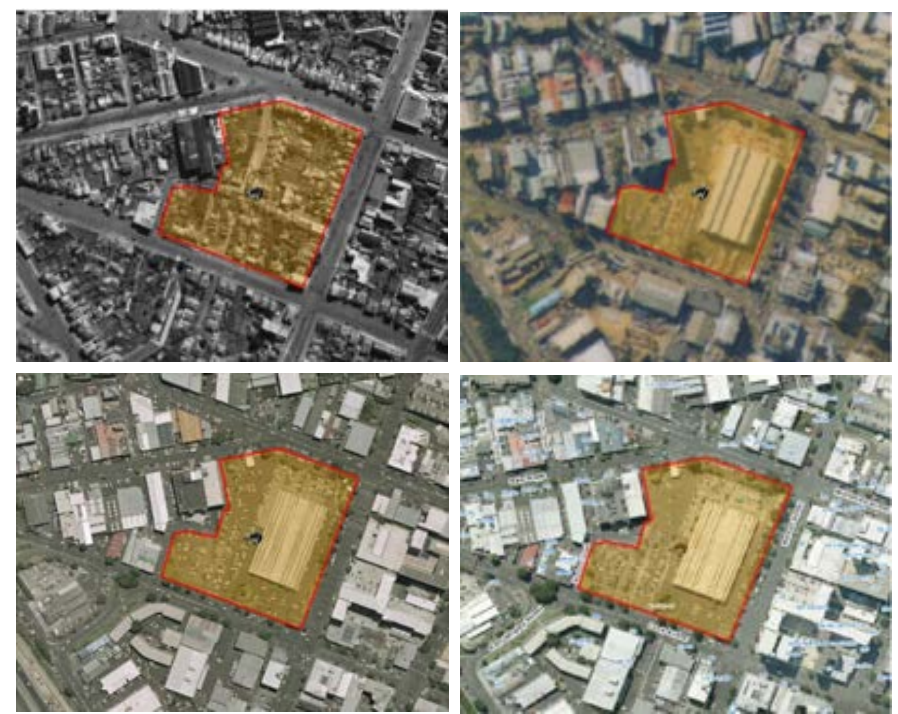

Figure 5. Historical aerial photography 1940-2010 (Auckland Council GIS Viewer)

\section{B. Zoning requirements}

Figure 6 below is a capture of Auckland City District Plan Victoria Quarter Area Section. The project site is located within the zone of the Western Strategic Management Area 3 (SMA3) - Victoria Quarter Area 2. The city blocks in this SMA are normally large and expose the industrial nature of the past. According to the District Plan, because of its strong industrial history and location, adjacent to the heart of the city, much of the Victoria Quarter can been seen as a "brownfields" area, representing a unique and considerable redevelopment opportunity.

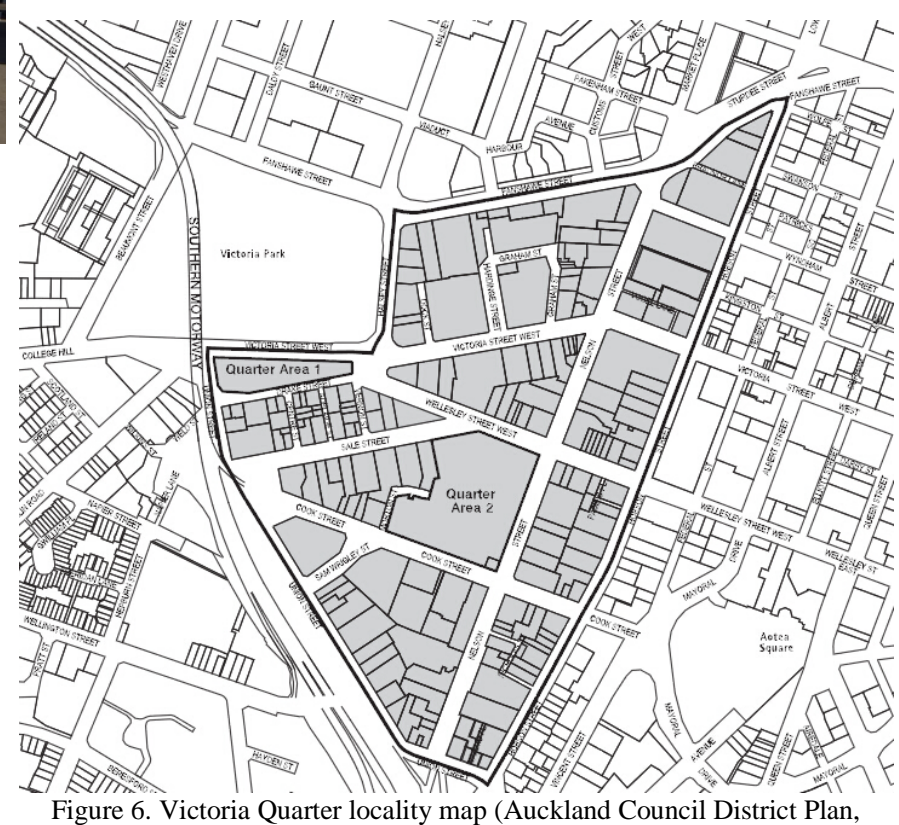

Figure 6. Victoria Quarter locality map (Auckland Council District Plan, 2012, p.3)

A feature of the existing built-in fabric of this area is its flexibility to accommodate a variety of activities - for commercial and residential uses or a combination of these. This useful quality enhances the possibilities for both commercial and residential developments. A significant portion of vacant and underutilized land exists in the western SMA, and it is the least developed of the three peripheral Strategic Management Areas.

\section{Property rates}

The 3.5 hectare property, which comprises four separate titles, has a \$44 million capital value and a land value of \$43.5 million (Auckland Council GIS Viewer, Table 1). There has been a significant increase in Auckland's CBD land values over the past two years because of a strong recovery on the office market [10]. 
TABLE I CITY WORKS DEPOT RATES INFORMATION (Auckland Council GIS Viewer)

\begin{tabular}{|l|l|}
\hline \multicolumn{2}{|c|}{ Rates Information } \\
\hline Location of rating unit & $\begin{array}{l}1-4 / 61-87 \text { Cook Street Auckland Central } \\
\text { Auckland } 1010\end{array}$ \\
\hline For period & 1 July 2014 to 30 June 2015 \\
\hline Assessment number & 00100772532 \\
\hline Valuation number & $10 / 0440 / 017 / 00 / 05$ \\
\hline Valuation as at date & 1 July 2011 \\
\hline Capital value & $\$ 44,000,000$ \\
\hline Land value & $\$ 43,500,000$ \\
\hline & Lot 1 DP 422053 6265m2, Lot 2 DP \\
Description of rating unit & 422053 7700m2, Lot 3 DP 422053 \\
& $10575 m 2$, Lot 4 DP 422053 4370m2 \\
\hline
\end{tabular}

\section{Incentive motives and financial considerations involved in adaptive reuse}

The current property owners, who are also the property developers, have been involved in the operation of this site since 2000. Since then, they have leased it for parking uses and are very familiar with this property as well as have a wide knowledge of it. However, the property was not available for purchase until 2012 when they took part in the Bayleys' tender, together with eight other bidders, and won it for an undisclosed price. A determining factor for the purchase was the land and its prime location adjacent to the CBD. "The land was the fundamental thing for choosing this particular building" (DEVELOPER). The developers believed that the main value was in the land, as it offered good development opportunities. "We like land. Land appreciates, buildings do not" (DEVELOPER) while less and less land is available in the CBD fringe. The building itself, site size, use, and commercial potential were also aspects that drew the current owners' interest, but these were secondary to the land proposition. "The buildings themselves have good bones and have tremendous commercial potential. You just can't find anywhere something like this in the city. It's unique" (DEVELOPER). Similarly, the project architect commented that the large size of the site in the middle of the city and the building's scale were unique to the central city.

The CWD is owned by the private sector; therefore, the private property owners are the main decision-makers who choose whether to adaptively reuse the buildings to accommodate new uses or demolish and reconstruct. Although these industrial buildings, like many others in Auckland's inner city, are not registered with the NZHPT and had consent for demolition, the property developers showed real appreciation of industrial heritage and decided to preserve and convert them rather than demolish. Various adaptation schemes are worthwhile in most cases and have economic, social and environmental benefits. In addition, they provide certain financial gains and returns [1]. Often, it is more economical to adapt an existing building stock than to demolish and replace it as the adaptation process is generally shorter than that of new construction and the infrastructure already exists [14] [2] [36] [49]. The interview data suggests that the economic benefits were a key decision-making factor for the private property developers. The environmental benefits of adaptive reuse, such as reducing energy consumption and generation of waste, and minimizing pollution, although extensively covered in the literature [5] [14] [51] [52], were not specifically mentioned by the developers and were not the main purpose. The long-term social benefits of the retention of existing buildings, from an architectural, cultural, and historical perspective [1] [7] [49], were a part of the decision-making process, although on the basis of revenue generation.

The most important financial consideration for the property developers was the actual return on investment. The property owners/developers, who saw the potential of the buildings, decided to retain and reuse them adaptively and then lease them, instead of building new buildings on the site in an economic climate which was unfavourable. They believed that the vast scale of the site would continue to appreciate. "We are not going to build anything new on the site. We could get a better return from the buildings than we could off the land" (DEVELOPER).

The adaptation costs were of main concern. The property developers believed that the conversion costs depended on the building itself. "If the building itself has beautiful bones, the costs of the project can be significantly simplified and reduced" (DEVELOPER) which was the case with this development. "We didn't need to spend too much money to make them [the buildings] lettable" (DEVELOPER).

The holding period was also a matter of consideration. In the long run, profits are made through the increase in value. However, in the short term, there may be little or no profits from leases after expenses like mortgage, rates, insurance, and maintenance costs are taken into account. The current property owners were planning to keep this property for at least a generation for long-term results. "We have a vision for the City Works Depot. This property is worth more while the available land is getting less and less in the CBD fringe" (DEVELOPER).

Leasing arrangements influence depreciation and maintenance expenses, and other costs and ratios on the income statement. As the project site is a development site, the value is in the land. Consequently, the current owners were just looking for 6-8 years of commitments and leased $15,000 \mathrm{~m}^{2}$ out of the $20,000 \mathrm{~m}^{2}$ total floor space. "If we lease longer than 8 years, then we cannot borrow as much money against the property. The property is worth more with no leases than with long-term leases, so this is a bit of a balancing act" (DEVELOPER).

The on-going maintenance costs of an adapted building and the age of the materials have to be taken into consideration as well as. Although resource consent for the mixed-use of residential, retail and office spaces was granted for this project, the current owners chose the mixed-use of retail and office development after considering the cost and building consent issues. "Residential is too expensive to build and requires more management. It triggers all sorts of building consent issues - fire compliance, etc.," (DEVELOPER). The findings of this study regarding actual return on investment, and adaptation and maintenance costs are consistent with the literature stating that a complicated adaptation or poor construction quality can raise the adaptation costs higher than the cost of a new building [52]; 
capital and ongoing maintenance costs would often be higher than a new-build project as the building ages over time [6] [14] [53]. The interview data also suggests that holding periods and leasing arrangements, both related to the actual return, were equally important for property developers but had limited coverage in the literature.

\section{E. Design considerations involved in adaptive reuse}

The design considerations are divided into three groups architectural, construction and regulatory. The interview data suggests that the CWD's proactive private property owners/ developers played a key role in the overall successful building adaptation and the district's urban regeneration. They fit the description in the literature that new entrepreneurs and investors are particularly attracted to the oldest city districts and neighbourhoods [40] and appreciate the potential offered by the urban landscapes in heritage districts or the so called "geographical capital" [24]. The property owners/developers had commissioned a well-respected registered architectural firm, graphic and spatial designers for the design of the interior renovations as design was important for them. They felt very passionate about the redevelopment of the property and had a flair for design. Hence, compromising on quality was not an option as they were planning to keep the property for a long term. Investing in good design became part of this overall plan. Furthermore, the property owners/developers played a part in influencing the design with own ideas or discussed sources of inspiration and thus became involved in the process.

The main architectural concern was the master planning due to the large size of the site. The project architect commented that he needed to define the uses and programmes of each part of the building at a very early stage to ensure they would satisfy also the needs of any future development and not conflict with the existing built environment. "The building cannot just be visually attractive; it also has to be highly functional" (ARCHITECT). One example was the consideration of the sunlight in terms of better lighting which is essential for good-quality office space and could make the building attractive from a tenant's point of view. Car parking numbers and the specific layout were also a challenge for this site as they could generate additional profit for the owner. "If lower deck development takes out 20 car parks, we must make sure the development can gain more than 20 car parks from elsewhere" (ARCHITECT). Master planning is a major process concerned with the compatibility of the building's new use with its surroundings [14].

Protecting the building's historical significance was also taken into consideration to retain its external and internal features. Although this property has not been identified as having historical value, the reinforced steel frame structure is unusual in Auckland, and the astonishing artillery-style sheds, which were preserved, are an embodiment of historical narratives. All interviewed stakeholders unanimously agreed on the building preservation and appropriate adaptation. "We understand and respect the history and great achievements of the architecture and plan to retain the buildings. We will create a desirable district for high-profile businesses that proliferate this side of the Auckland CBD” (DEVELOPER). Part of retaining the building's value is to take careful consideration of the existing materiality, proportion, structural steel set out, and grid line; understand the existing language of the building; and carry this understanding forward. "The building's history supports cultural memory that is worth preserving. There is a very strong structural grid to the building and the proportion of the building is very unusual. I think any new work should pick up on this grid and the geometry of the existing building" (ARCHITECT). "We actually exposed the beams. It was re-cladded, re-glazed, and repaired to keep its original features" (ENGINEER). "The warehouse type of buildings in the Victoria Quarter district contribute to the city character" (HERITAGE ADVISOR).

These findings are in agreement with studies in the literature that building adaptation supports cultural memory and also restores and maintains the heritage significance of the building itself [7] [18] [49]. However, these findings do not support claims of other studies that adaptive re-use remains an "anathema" to many architects and most of the building professions [21] and "many architects believe that adapting older buildings for multiple uses is less prestigious than constructing new ones, and inhibits their creative opportunities” [7, p.37].

In terms of structural considerations, structural adequacy was the main concern on this project as conversion complications depend on how much information you have. "If you got good information, like the City Works Depot got good initial drawings, it's not that difficult because we know everything about the foundations and all the detail. But if you got no information, particularly concrete masonry, it is a lot more difficult" (ENGINEER). The original condition of the building was a concern; in comparison to the poor conditions of Sheds 1\&2, Shed 12 was in a reasonably good condition. 


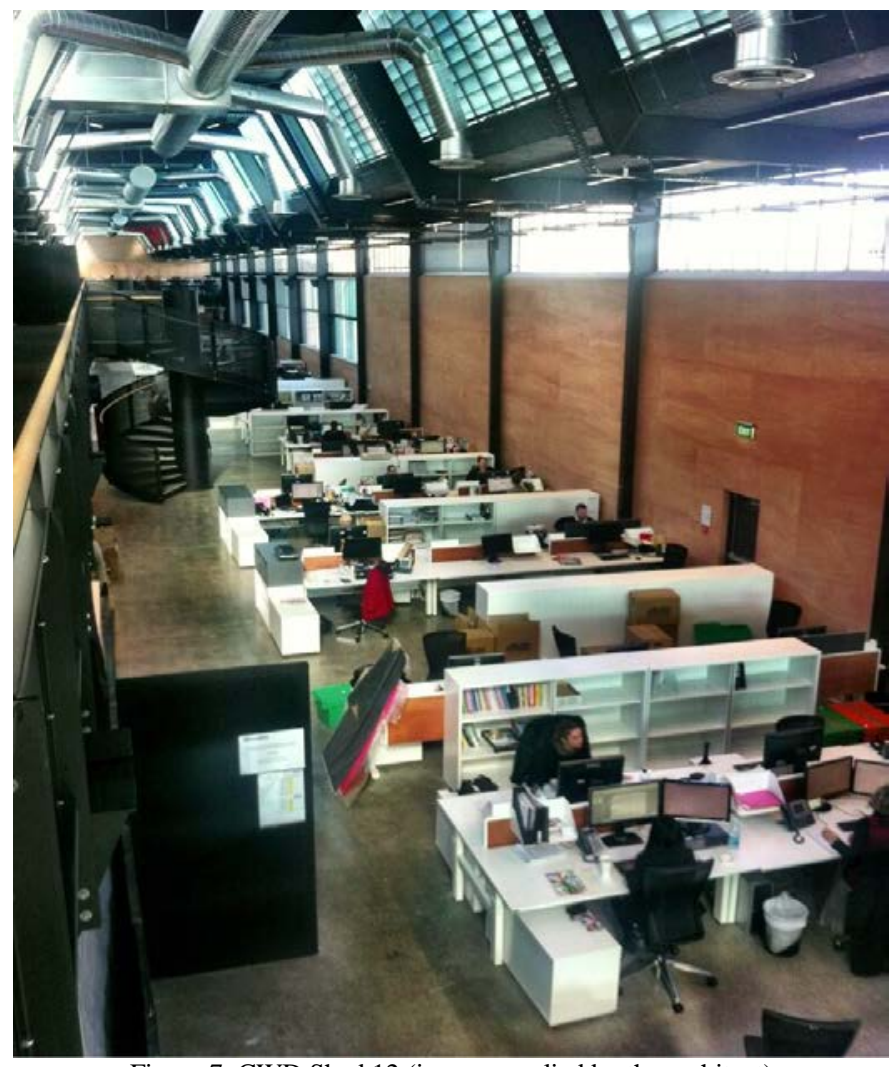

Figure 7. CWD Shed 12 (image supplied by the architect)

However, the engineer explained that they were stuck with the mezzanine floor, which was the main barrier and challenge they encountered. The proposed light timber mezzanine required new longer spans and floor joists that they did not normally used and because they were adding load to it, they had to show that it was still straight. Further provisions needed to be made for unforeseen on-site issues, such as a structure that is out of line, a wall that is not straight, pipework below the concrete slab, tightened waterproofing inspection, etc. "The best way to overcome these problems is to work with the tradespeople directly on site, and use their very special knowledge and direct it with our architectural intention, so we don't make compromises on design work. These issues are part of the making of architecture" (ARCHITECT). Adaptation complexity and build quality are associated with adaptive reuse costs [52].

In terms of regulatory requirements, the City Centre team at Auckland Council aims to support the City Centre Master Plan and seeks to achieve quality planning outcomes and consistency with the Resource Management Act (RMA) requirements. As the project site is within the Victoria Quarter Area 2 in the district plan, mixed-use activities such as accommodation, food and beverage and education are all permitted for this area. All precinct's buildings had a demolition resource consent granted on 28 May 2007. A comprehensive site master plan was proposed for 20 new buildings of mixed-use development, including 1,084 residential units, 360 restaurants or office spaces, and 3,793m2 of retail, food/beverage, and service activities. Instead, all buildings were preserved. "Current use represents a very good interim mixed-use of the site, without ruling out future development that will maximise the potential of the site and include residential use" (PLANNER). Compliance with the Building Code is also a common challenge, such as disabled access, fire egress, etc. The important regulatory considerations for industrial building conversions also include safe pedestrian access around the site, redevelopment of potentially contaminated land, compliance with noise limits (in bars and other entertainment centres), comprehensive site structure planning/securing public access, site links and loading, servicing, storage facilities, collection and disposal of refuse, and others. Building adaptation is harder to achieve given the standards required [7], which is especially true for mixed-use conversions, one of the most complicated amongst the conversion methods [14]. Furthermore, indoor air quality and acoustic and thermal performance requirements are major concerns [52].

\section{F. Criteria for tenant mix selection}

The process of acquiring suitable tenants was essential to the success of the "fledgling precinct" (ARCHITECT). The main vision of the property owners was to build a selfsustaining community through the selection of businesses inventing things every day or makers of things. "Those things could be intellectual, but they could also be physical" (DEVELOPER). The property developers identified the key criteria for the selection of the mixed-use precinct's tenant mix: strong covenant, easy to deal with tenants and businesses with creative flair. A good tenant mix means having different types of businesses that work well together to enhance the overall performance of the property instead of performing successfully as an individual business [30]. Prior assessment of the covenant strength of a prospective tenant was considered necessary before signing the lease agreement. The tenant's financial stability and profitability were considered essential for the owner in order to make sure the business can realistically afford the rent.

The interview data revealed that rents in converted industrial buildings in the inner city are on a par with rents in modern office buildings in the CBD and CBD fringe areas mostly due to the character building stock and associated branding. These findings contradict statements in the literature that "the use of older properties can enable occupiers at the lower end of the rental market to occupy buildings in locations where normally they would only have the choice of newer buildings at much higher rent levels" [7, p.37]. However, despite the property owners' interest in maximising profit, strong covenant was not the only criterion for them to make a selection. The management cannot take on tenants simply because they can afford the rentals [26].

Once the owner approves the prospective tenant's ability to afford the rent, then he considers other traits of the tenant's personality to make sure the tenant is easy to get along with, which will hopefully prevent poor communication. These qualities were considered as advantages in difficult situations especially when negotiating rent reviews or when cooperation in the maintenance and building operational issues was required. It is necessary to understand what the potential tenants are looking for when they come to your property [26]. 
There was a particular preference for "people who were driving really interesting, creative businesses, and who, by culture, were committed to being not in generic space but in more adventurous space" (ARCHITECT). "Cool and great businesses. Somewhere we would like to hangout" (DEVELOPER). As the CWD's planners decided on a "no plasterboard" philosophy, this determined the type of tenants appropriate to the buildings [3]. "Part of it was finding the people with the right attitude to the buildings ... who would embrace the profiled steel walls and the steel girders and columns flying through the spaces" (ARCHITECT). The businesses that fitted the criteria were the advertising agency Y\&R, the Three Beans Roastery, Brothers Brewery, Al Brown, the Shed Five Café and the Food Truck - "all those people, whether they are writing software, or brewing beer on site, are making something" (DEVELOPER).

\section{CONCLUSION}

This research investigated the key areas of consideration involved in the conversion of former industrial buildings in a new large-scale precinct in Auckland's CBD. The adaptive reuse project's economic value was the main driver for the private property owners/developers. Social and environment benefits were secondary and of less importance to them. Hence, the financial considerations, such as actual return on investment, adaptation costs and maintenance costs were key, a finding which conforms to the literature. However, this study revealed that the holding period and leasing arrangements were also considered important.

The project architect, structural engineer, urban planner and heritage advisor mainly focused on the design aspects architectural, construction, and regulatory. Master planning, structural adequacy of the original building, and compliance with building and planning regulations were the main considerations in the design stage. However, preserving the industrial heritage was equally important to the design professionals and property developers for whom the design needed to have good commercial sense to attract tenants. The determining criteria for tenant mix selection included strong covenant and good tenants with creative flair.

In conclusion in the case of Auckland, the urban commodification of the reconstructed industrial landscape is driven proactively by savvy private property owners/developers with entrepreneurial spirit who are able to identify emerging trends in their local economies and capitalise on them. As a result of the urban regeneration process converted industrial buildings begin to function as urban commodities. They are deliberately redeveloped as a new form of real estate which provides attractive working environments that target specifically creative, knowledgeintensive, technology-intensive and in recent years, service industries. Hence, character space and heritage is used as a commodity to promote a distinctive lifestyle in the context of post-industrial real estate development.

\section{REFERENCES}

[1] Australian Government Department of the Environment and Heritage. (2004). Adaptive reuse: Preserving our past, building our future. Canberra: Pirion.

[2] Ball, R. M. (2002). Reuse potential and vacant industrial premises: Revisiting the regeneration issue in Stoke-on-Trent. Journal of Property Research, 19(2), 93-110. doi: 10.1080/09599910210125223

[3] Barrett, M. (2013). Y \& R. Interior, Issue 7, March-May, 32-44.

[4] Buildings Department Hong Kong. (2012). Practice guidebook on compliance with building safety and health requirement under the buildings ordinance for adaptive re-use of and alteration addition works to heritage buildings, Hong Kong. Retrieved from http://www.bd.gov.hk/english/documents/guideline/heritage.pdf

[5] Bullen, P. A. (2007). Adaptive reuse and sustainability of commercial buildings. Facilities, 25(1/2), 20-31. doi: 10.1108/02632770710716911

[6] Bullen, P. A., \& Love, P. E. (2010). The rhetoric of adaptive reuse or reality of demolition: Views from the field. Cities, 27(4), 215-224. doi: 10.1016/j.cities.2009.12.005

[7] Bullen, P. A., \& Love, P. E. (2011). Adaptive reuse of heritage buildings. Structural Survey, 29(5), 411-421. doi: 10.1108/02630801111182439

[8] Burns, R. B. (2000). Introduction to research methods (Fourth ed.). London: Sage Publications Ltd.

[9] Cavana, R. Y., Delahaye, B. L., \& Sekaran, U. (2001). Applied business research: Qualitative and quantitative methods. Milton, Qld: John Wiley \& Sons Australia, Ltd.

[10] Colin, T. (2014). Multi choice downtown site. Retrieved from: http://www.nzherald.co.nz/property/news/article.cfm?c_id=8\&objectid= 11220650

[11] Cramer, J., \& Breitling, S. (2007). Architecture in existing fabric: Planning, design and building. Walter de Gruyter.

[12] Dear, H. (2013). Get to know the sheds: A history of the City Works Depot. Retrieved from: http://www.thecreativestore.co.nz/creativetalk/get-to-know-the-sheds/

[13] Denscombe, M. (2010). The good research guide for small-scale social research projects (Fourth ed.). Maidenhead: Open University Press.

[14] Douglas, J. (2006). Building adaptation (2nd ed.). Oxford: ButterworthHeinemann.

[15] Evans, G. (2001). Cultural planning: An urban Renaissance? London: Routledge.

[16] Evans, G. (2003). Hard branding the cultural city: From Prado to Prada. International Journal of Urban and Regional Research, 27(2), 417-440. doi: 10.1111/1468-2427.00455

[17] Evans, G. (2009). Creative cities, creative spaces and urban policy. Urban Studies, 46(5\&6), 1003-1040. doi: 10.1177/0042098009103853

[18] Fernandez-Galiano, L. (2000). Fire and memory: On architecture and energy. MIT Press.

[19] Fontana, A., \& Frey, J. H. (2000). From structured questions to negotiated text. In N. K. Denzin \& Y. S. Lincoln (Eds.), Handbook of qualitative research (Second ed., pp. 645-672). Thousand Oaks: Sage Publications, Inc.

[20] Gospodini, A. (2006). Portraying, classifying and understanding the emerging landscapes in the post-industrial city. Cities, 23(5), 311-330. doi: 10.1016/j.cities.2006.06.002

[21] Gregory, J. (2004). New South Wales department of housing rehabilitation: New ways for older housing. Retrieved from: www/housing.nsw.gov.au/rehab.htm

[22] Hannigan, J. (2003). Symposium on branding, the entertainment economy and urban place building: Introduction. International Journal of Urban and Regional Research, 27(2), 352-360. doi: 10.1111/14682427.00452

[23] Harper, D. (2000). Reimaging visual methods: Galileo to Neuromancer. In N. K. Denzin \& Y. S. Lincoln (Eds.), Handbook of qualitative research (Second ed., pp. 717-732). Thousand Oaks: Sage Publications, Inc.

[24] Helbrecht, I. (2004). Bare geographies in knowledge societies - creative cities as text and piece of art: Two eyes, one vision. Built Environment, 30(3), 191-200. doi: http://dx.doi.org/10.2148/benv.30.3.194.54299 
[25] Heritage Council of Victoria. (2012). Adaptive reuse of industrial heritage: Opportunities \& challenges. Retrieved from http://www.dpcd.vic.gov.au/_data/assets/pdf_file/0007/199105/HV_IP AWsinglepgs.pdf

[26] Highman, J. (2012). Big tips in tenant mix analysis for commercial real estate agents. Retrieved from: http://commercialrealestatetraining.com.au/big-tips-in-tenant-mixanalysis-for-commercial-real-estate-agents/

[27] Hutton, T. A. (2000). Reconstructed production landscapes in the postmodern city: Applied design and creative services in the metropolitan core. Urban Geography, 21(4), 285-317 doi: 10.2747/0272-3638.21.4.285

[28] Hutton, T. A. (2004). The new economy of the inner city. Cities, 21(2), 89-108. doi: 10.1016/j.cities.2004.01.002

[29] Hutton, T. A. (2006). Spatiality, built form, and creative industry development in the inner city. Environment and Planning A, 38(10), 1819-1841. doi: 10.1068/a37285

[30] Ibrahim, M. F., \& Galven, T. W. R. (2007). New age retail tenants: A new phenomenon. Journal of Retail \& Leisure Property, 6(3), 239-262.

[31] ICOMOS New Zealand. (2010). ICOMOS New Zealand charter: For the conservation of places of culture heritage value (Revised 2010). ICOMOS New Zealand.

[32] Johansson, M. (2012). Place branding and the imaginary: The politics of re-imagining a Garden City. Urban Studies, 49(16), 3611-3626. doi: $10.1177 / 0042098012446991$

[33] Julier, G. (2005). Urban designscapes and the production of aesthetic consent. Urban Studies, 42(50/6), 869-887. doi: 10.1080/00420980500107474

[34] Klingmann, A. (2007). Brandscapes: Architecture in the experience economy. Cambridge, Massachusetts: The MIT Press.

[35] Kurul, E. (2007). A qualitative approach to exploring adaptive re-use processes. Facilities, 25(13/14), 554-570. doi: 10.1108/02632770710822634

[36] Langston, C., Wong, F. K. W., Hui, E. C. M., \& Shen, L. Y. (2007) Strategic assessment of building adaptive reuse opportunities in Hong Kong. Building and Environment, 43(10), 1709-1718. doi: 10.1016/j.buildenv.2007.10.017

[37] Markusen, A. (2006). Urban development and the politics of a creative class: Evidence from a study of artists. Environment and Planning A, 38(10), 1921-1940. doi: 10.1068/a38179

[38] Markusen, A. (2007). The urban core as cultural sticky place. In D. Henckel, E. Pahl-Weber \& B. Herkommer (Eds.), Time space places (pp. 173-187). Berlin: Peter Lang Verlag.

[39] Merriam, S. B. (2009). Qualitative research: A guide to design and implementation (Second ed.). San Francisco: Jossey-Bass.
[40] Montgomery, J. (2007). The new wealth of cities: City dynamics and the fifth wave. Aldershot, Hampshire: Ashgate Publishing Ltd.

[41] Morse, J. M., \& Richards, L. (2002). Readme first for a user's guide to qualitative methods. Thousand Oaks: Sage Publications, Inc.

[42] Neuman, W. L. (2003). Social research methods: Qualitative and quantitative approaches (Fifth ed.). Boston: Pearson Education, Inc.

[43] Remoy, H., \& Van der Voordt, T. (2014). Adaptive reuse of office buildings into housing: Opportunities and risks. Building Research \& Information, 42(3), 381-390. doi: 10.1080/09613218.2014.865922

[44] Schittich, C. (2003). In detail building in existing fabric: Refurbishment, extensions, new design. Basel: Birkhauser.

[45] Scott, A. (2004). Cultural-products industries and urban economic development: Prospects for growth and market contestation in globa context. Urban Affairs Review, 39(4), 461-490. doi 10.1177/1078087403261256

[46] Shetty, P. (2004). Rethinking heritage: The case of heritage conservation in Mumbai. Retrieved from http://cityscans.wordpress.com/urbanism/rethinking-heritage/

[47] Short, J. R., Benton, L. M., Luce, W. B., \& Walton, J. (1993). Reconstructing the image of an industrial city. Annals of the Association of American Geographers, 83(2), 207-224. doi: 10.1111/j.14678306.1993.tb01932.x

[48] Soja, E. W. (2000). Postmetropolis: Critical studies of cities and regions. Oxford: Blackwell Publishers Ltd.

[49] Tooley, R. (2011). A new purpose for old buildings. Retrieved from http://rebeccatooley-rechargingstations.blogspot.co.nz/2011/11/newpurpose-for-old-buildings.html

[50] Wang, J., \& Nan, J. (2007). Conservation and adaptive reuse of historical industrial building in China in the post-industrial era. Frontiers of Architecture and Civil Engineering in China, 1(4), 474-480. doi: 10.1007/s11709-007-0064-5

[51] Wang, H. J., \& Zeng, Z. T. (2010). A multi-objective decision-making process for reuse selection of historic buildings. Expert Systems with Applications, 37(2), 1241-1249.doi:10.1016/j.eswa.2009.06.034

[52] Wilkinson, S. J., James, K., \& Reed, R. (2009). Using building adaptation to deliver sustainability in Australia. Structural Survey, 27(1), 46-61. doi: 10.1108/02630800910941683

[53] Yung, E.H.K., \& Chan, E.H.W. (2012). Implementation challenges to the adaptive reuse of heritage buildings: Towards the goals of sustainable, low carbon cities. Habitat International, 36(3), 352-361. doi:10.1016/j.habitatint.2011.11.001

[54] Zukin, S. (1982). Loft living: Culture and capital in urban change. Baltimore: John Hopkins University Press. 